Relations industrielles

Industrial Relations

\title{
The Docks After Devlin, by Michael Mellish, London, Heinemann Educational Books, 1972, 146 pp.
}

\section{A. Peach}

Volume 28, numéro 4, 1973

URI : https://id.erudit.org/iderudit/028460ar

DOI : https://doi.org/10.7202/028460ar

Aller au sommaire du numéro

Éditeur(s)

Département des relations industrielles de l'Université Laval

ISSN

0034-379X (imprimé)

1703-8138 (numérique)

Découvrir la revue

Citer ce compte rendu

Peach, D. A. (1973). Compte rendu de [The Docks After Devlin, by Michael Mellish, London, Heinemann Educational Books, 1972, 146 pp.] Relations industrielles / Industrial Relations, 28(4), 887-888.

https://doi.org/10.7202/028460ar

Tous droits réservés @ C Département des relations industrielles de l'Université Laval, 1973
Ce document est protégé par la loi sur le droit d'auteur. L'utilisation des services d'Érudit (y compris la reproduction) est assujettie à sa politique d'utilisation que vous pouvez consulter en ligne.

https://apropos.erudit.org/fr/usagers/politique-dutilisation/ 
mancipation a perdu sa force attractive auprès de la jeune génération. Le syndicalisme qui était un instrument de libération contre l'oppression est devenu un moyen d'améliorer une situation et d'apporter un mieux être. Et cette tendance a été renforcée par les changements survenus dans la structure de la main-d'œuvre. On s'oriente vers une action syndicale selon le modèle américain, qui se concentre surtout sur la négociation collective, des politiques à court terme et des résultats matériels. La négociation collective s'étend à un plus grand nombre de travailleurs et couvre plus de matière. En certains pays, cette négociation se place au niveau de l'industrie ou du gouvernement et ailleurs, au niveau des établissements. Ceci a une influence sur le caractère que prennent les syndicats. Ce qui amène l'auteur à distinguer entre deux types de syndicalisme: syndicalisme gestionnaire (administrative union) et syndicalisme négociateur (bargaining union), le premier orienté vers la participation à la gestion des entreprises comme en $\mathrm{Al}$ lemagne ou à la fixation de politiques économiques et sociales avec l'Etat, te second visant à la négociation collective dans les établissements. La distinction n'est pas étanche aujourd'hui avec l'importance que prennent les problèmes qui relèvent de l'économie entière ou de la politique comme le plein emploi et l'inflation, les syndicats se voient écartelés dans leur action. D'une part ils doivent rester en contact avec la base et répondre aux besoins immédiats de leurs membres, d'autre part, ils doivent assumer des responsabilités dans des politiques générales qui viennent en opposition avec la recherche de ces intérêts immédiats. Le pouvoir qu'ils ont acquis et la pression de l'opinion publique peuvent forcer les syndicats à modifier leur rôle de groupement d'intérêt privé et à considérer davantage le contexte général dans lequel ils ont à agir. Comment en arriver à un équilibre entre ces deux exigences sans qu'il se crée, comme on l'a observé en Grande-Bretagne, un double système de relations industrielles? L'auteur craint qu'en raison du poids de la tradition qui pèse fortement sur le syndicalisme européen, celui-ci ait de la difficulté à relever le défi et il n'écarte pas la possibilité de le voir dépassé par les événements.

Il est toujours enrichissant de lire les ouvrages d'Adolf Sturmthal qui est un des grands spécialistes du mouvement syndical comparé. Celui-ci, cependant, en raison de sa brièveté devant l'ampleur du sujet traité et la difficulté des questions soulevées laisse souvent le lecteur sur son appétit et on aimerait voir l'auteur développer davantage. Néanmoins, il fournit beaucoup de matière à réflexion et stimule les interrogations qu'on doit se poser sur les orientations que prendra le syndicalisme.

Université Laval

Gérard DION

The Docks After Devlin, by Michael Mellish, London, Heinemann Educational Books, 1972, $146 \mathrm{pp}$.

The trouble with this book lies not in the book itself, but in the events that have followed.

Basically, the book is a description of the implementation of the 1965 recommendations of the Devlin Committee in the British longshore industry. Unfortunately, the book, a detailed study of three firms in one sector of the London docks, recounts events only up to mid1971 , and significant events have occurred since that time.

The Devlin Committee recommended an end to casual employment on the docks, a change in compensation to daywork from piecework, the elimination of certain «featherbedding 》 practices, reforms in union organization, and improvements in intra-union communication. The chief thrust of the reforms was to improve labour relations in the British dock industry, by increasing employee job and wage security, these being the main determinants of the strife which had historically existed.

Mr. Mellish's study does a satisfactory job of describing the implementation of the recommendations, some of which were more successfully done than others. The book is a little short of specific illustrations as to exactly how the changes were made, however. Of some importance is the author's discussion of how many of the problems in the docks were managarially induced, and not caused by the workers or their unions.

In July of 1972 , a little more than a year after the study ended, the British docks erupted again - over job security. 
the 3-day strike which followed, while in part concerned with the British labour movement's attack on the new Industriai Relations Act, was an attempt to reduce the impact of containerization on the dock workers. The fault of Devlin, and thus of this book, was that it failed to consider this issue. The book is really only a study of the docks for a limited time after Devlin. While the reforms instituted by Devlin were indeed major, they were not complete enough to solve the industrial relations problems on the docks. As a result, the complete story of the recent history of the British longshore industry remains to be written.

The University of Western Ontario

\section{Professors, Unions, and American Higher}

Education, by Everett Carl Ladd, Jr., and Seymour Martin Lipset, Washington, D.C. American Enterprise Institute for Public Policy Research; Berkeley, California, Carnegie Commission on Higher Education, 1973, 125 p.

Contrairement à l'expansion considérable de la dernière décennie, l'enseignement supérieur devrait connaître pour une assez longue période une austérité relative. Ce changement ne peut qu'encourager la pénétration du syndicalisme chez les professeurs d'université. Dans les institutions publiques, ils feront de moins en moins confiance aux administrateurs d'université comme porte-parole dans les négociations avec le gouvernement pour déterminer l'importance des crédits de l'enseignement supérieur.

Financé par la Carnegie Commission on Higher Education, ce court volume fait le point sur la montée du syndicalisme chez les professeur des universités américaines. Il peut être divisé en 2 parties: les cinq premiers chapitres fournissent une bonne documentation sur la percée du syndicalisme dans l'enseignement supérieur, sur les trois groupes syndicaux en présence aux Etats-Unis et les opinions des universitaires sur le phénomène. Les deux derniers chapitres d'une quarantaine de pages, plus analytiques, tentent de délimiter les effets fort importants de la syndicalisation sur l'enseignement supérieur. Ces piges devraient être étudiées par toute personne intéressée par le sujet. Les références nombreuses des auteurs énumérées à la fin du volume constituent par ailleurs une excellente bibliographie.

A la fin de 1972, la syndicalisation comprenait le sixième du corps professoral, soit 55,000 professeurs sur un total de 330,000 , avec 90 pour cent des unités de négociation dans les institutions publiques et le plus souvent dans celles de moindre prestige, où le professeur ressemble à son collègue de l'enseignement secondaire avec l'emploi exclusif de son temps à l'enseignement. Le taux de pénétration syndicale plus élevé dans ce milieu montre que l'idéologie plus conservatrics de ce «prolétariat» universitaire n'a pas suffi à compenser les effets des conditions de travail moins intéressantes.

Quelles sont les implications probables de la syndicalisation sur l'enseignement supérieur? Ladd et Lipset partage en quatre points leur analyse : la parité salariale, le renouvellement d'emploi et la permanence, la gestion universitaire, et enfin, les tensions entre les professeurs et les étudiants. Du côté salarial, la syndicalisation élimine les écarts de traitement à l'intérieur d'une même catégorie d'emploi à l'exception de ceux reliés à l'ancienneté. Il en est de même du côté de la permanence d'emploi : la syndicalisation favorise le renouvellement automatique et la permanence pour le jeune professeur qui ne doit satisfaire qu'à des exigences minimales de compétence et ainsi se soustraire aux jugements (et parfois au népotisme) des collèguss plus âgés. Les auteurs situent le tout dans le cadre plus global de la société : "From the broadest perspective, the rapid growth of collective bargaining in higher education during the past half-decade should be seen as the extension - to the level of university governance and faculty life - of the powerful trends toward equalization and away from elitism that have characterized many sectors of American society since the mid-sixties $\gg$ (p. 103).

La formulation et l'implantation de règles détaillées inhérentes au contact de travail affaiblissent la notion d'université comme «coopérative de producteurs》 avec un degré élevé de co-gestion, pour accentuer les relations conflictuelles entre employeurs et employés. Née en partie de la bureaucratisation des universités, la 